\title{
Sınıfsal Karşılaşmaları Kültürel Sermayeler Üzerinden Okumak: Ankara, Kurtuluş İkinci El Eşya Satıcıları
}

\author{
DOI: $10.26466 / o p u s .572111$
}

*

\section{Furkan Dilben $^{*}$}

*Doktora Öğrencisi, Hacettepe Üni., İletişim Fak., İletişim Bil. Doktora Programı Ankara / Türkiye E-Posta: furkandilben@gmail.com

ORCID: 0000-0003-1161-0704

\section{Öz}

Hızlanan kentleşme süreci ile birlikte kırsal alandan, iş olanaklarının arttığı kentlere doğru gö̧̧ yoğunlaşmıştır. Ayrıca kentlerde kurulan yeni üniversiteler de göç hareketliliğinde ç̧eşitliliği arttırarak, öğrencilerin geçici olarak eğitim hayatlar boyunca şehir değiştirmelerine neden olmuştur. Bunun sonucunda kentlerde hem yeni iş sahaları ortaya çıkmış, hem de farklı kültürel ve sosyal sermayeden insanların karşılaşma ihtimali artmıştır. Bu yeni iş sahalardan biri de, bekârlara, yoksullara ya da orta sınıftan insanlara ve çoğunlukla öğrencilere hizmet veren ikinci el eşya satıcılı̆̆ıdır. Öğrencilerle ikinci el eşya satıcılarının yoğun teması, farklı kültürel ve sosyal sermayenin karşı karşıya gelmesine neden olmaktadır. Genellikle üniversite eğitimi almamış olan fakat ekonomik sermayesi öğrencilerden daha fazla olan ikinci el eşya satıcılarn ile öğrencilerin kültürel sermayeleri oldukça farklıdır. Çalışmanın amacı, bir bölgede tamamen ekonomiye indirgenemeyecek gündelik yaşamda sıradan görünen sımıssal karşılaşmaları kültürel karşılaşmalar üzerinden okumaktır. Daha önce akademik olarak gündeme getirilmemiş olan bu kesişim, yapılan saha çalışması ile desteklenip, sahanın sesini ön plana çıkararak işlenmektedir.

Anahtar Kelimeler: Habitus, Kültürel Sermaye, Sosyal Sermaye, Öğrencilik 


\title{
Reading Class Confrontations with The Help Of Cultural Reproduction: Second-Hand Store Owners In Ankara, Kurtuluş
}

\begin{abstract}
Migrations from rural areas to urban areas that have increasing job opportunities, are intensified with the accelerating urbanization process. Besides, newly-established universities in urban areas have expanded the variety of migration, causing students to temporarily move another city during their education life. Therefore, new fields of work emerged in the cities, and people had better chance to confront people from various cultural and social reproductions. One of these new fields of work is second-hand store ownership which offers service to single, poor or middle-class people, and especially to students. The close link between second-hand store owners and students cause distinct cultural and social reproductions to confront. The cultural reproductions of second-hand store owners who, generally, do not have a college degree, but have better economic capital than students, are quite divergent from students'. The aim of this study is to read class confrontations, which cannot be degraded only to economy, and seems ordinary in daily life, with the help of cultural reproduction. This intersection that has been never brought forward in academia, is studied supported by fieldwork, and featuring the sound of field upfront.
\end{abstract}

Keywords: Habitus, Cultural Reproduction, Social Reproduction, Studentship 


\section{Giriş}

Türkiye'de 1950'lerde hızlanan kentleşme süreci, kırsal alandan pek çok insanın kentlere göçmesine sebep olmuştur. Kentlere, kırsal alandaki iş imkânlarının yetersizliğinden ötürü göç yaşandığını söylemek mümkündür; ancak bu göç hareketinin sonuçta kentteki iş imkânlarını arttırdığını da söyleyebiliriz. Bunun yanı sıra kentlere yapılan yatırımlar sonucu üniversite ve hastane gibi kamu kuruluşlarının açılması da kentlerdeki iş hareketliliğini arttırmıştır.

Kentleşme sürecinin ve göç hareketliliğinin, günümüzde sona erdiğini söylemek pek mümkün değildir. Halen pek çok sebeple insanlar farklı kentlere -geçici ya da kalıcı olarak- göç etmektedir. Bu çalışma kapsamında, Ankara'da bulunan, etrafında, yürüme mesafesinde pek çok üniversitenin yer aldığı Kurtuluş semtindeki bir iş sahasına bakılacaktır: İkinci el eşya satıcıları, bir diğer kullanımıyla spotçular ${ }^{1}$. Spotçuların bu bölgede, en yoğun ilişki içinde oldukları üniversite öğrencileri ise sahanın dinamiklerine eklenen aktif bir bileşen olarak önem kazanacaktır.

Seneler evvel Ankara'ya yerleşen, çeşitli işlerde çalıştıktan sonra Kurtuluş'taki nüfus hareketliliğinin potansiyelini fark edip ikinci el eşya dükkânı açan spotçular, müşterilerinin büyük kısmını oluşturan öğrencilerle sürekli iletişim halindedirler. Öğrencilerle spotçuların yoğun etkileşimi daha önce akademik bir çalışmaya konu edilmemiştir. Bu etkileşim, çalışmanın temel merakını ve motivasyonunu oluşturmaktadır.

Spotçularla öğrencilerin iletişiminde kültürlerarası karşılaşmanın farklı boyutları gerçekleşir. Kimi zaman, İstanbul'dan gelen bir öğrenci karşısında köylüleşen spotçular, Diyarbakır gibi kırsaldan gelen bir öğrenci karşısında ise kentlileşir. Kimi zaman ise sınıfsal durumu kat be kat daha iyi olsa da, öğrencinin okumuşluğunun karşısında kendini ezilmiş hissederler. Zaman zaman okumaya övgüler dizen spotçular, zaman zaman da öğrencilerin kendisine vermediği selamı eşek okusa ne olur benzeri söylemlerle tam tersinde okurlar. Görünüşe göre okumuş olmak,

\footnotetext{
${ }^{1}$ Spotçu, TDK'ya göre "bir malı çok miktarda toptancıdan veresiye aldıktan sonra piyasada değerinden daha aşağıya peşin olarak satan kimse" anlamına gelen ticari bir kelimedir. Ancak bu metinde spotçu, sahada kullanıldığı biçimiyle ikinci el eşya satan kişi anlamındadır. Bu metin için yapılan sahada görüşülen kişiler evlerden ikinci el ürün alıp dükkânlarında satmaktadır.
} 
spotçular için erdemli davranış kalıpları içerisine girmeyi gerektirir ve bir farklılığa işaret eder.

Henri Lefebvre (2012a, s.137), insanı çok uzaklarda ya da çok derinlerde, bulutların üzerinde ve hatta gizemlerde aramak gibi zahmetli bir sürece katlandığımızı; oysa insanın bizi yakınımızdaki her yerde beklediğini ve çözülmeye hazır olduğunu söylemiştir. Bundan ötürü, bazen yapmamız gereken, gözlerimizi açmak ve insana dair en derin mevzuları basitliğin içinde, yakınımızda yani gündelik hayatta aramak gerekir. Bu çalışmanın amacı, bir bölgede tamamen ekonomiye indirgenemeyecek gündelik yaşamda sıradan görünen sınıfsal karşılaşmaları kültürel karşılaşmalar üzerinden okumaktır.

Büyük bir iddia olabilir ancak öğrencilik deneyiminin Türkiye'de zaman zaman ötekileştirilmeye uğradığını söyleyebiliriz. Örneğin, hükümet tarafından 2013 senesinde kızlı-erkekli öğrencilerin aynı evde kalmaları meselesi gündeme getirildiğinde, bazı öğrenciler farklı şekillerde baskıya maruz kalmışlardır. Öğrenciden daha yüksek kira istenmesi ya da öğrenciye kiralık ev verilmemesi şeklinde damgalanma gibi farklı örneklerle beraber öğrencilerin ev bulmaları ya da eşya edinmeleri gibi pek çok mesele onları zora sokabilmektedir. Maddi ya da diğer pek çok sebeple öğrencilerin iletişime geçtiği esnaflardan biri de, kaçınılmaz olarak ikinci el eşya satıcılarıdır. Ekonomik durumu iyi olmayan öğrencilerin ev ihtiyaçlarını en uygun fiyata karşılamaları gerekmektedir; bunu yapabilmenin en uygun yolu da çevredeki ikinci el eşya satıcılarıdır. Bu zorunlu ilişki iki ayrı sermayeyi karşı karşıya getirmektedir. Çoğunlukla üniversite eğitimi almamış ama ekonomik olarak öğrencilerden daha iyi durumda olan ikinci el eşya satıcıları ile ekonomik olarak durumu yeterli olmayan öğrencilerin kültürel sermayeleri oldukça farklıdır. $\mathrm{Bu}$ karşılaşmalarda ikinci el eşya satıcılarının deneyimlerinin -diğer müşteri gruplarından ayırarak ve farklarını da anlamaya çalışarak- tartışılması amaçlanmaktadır.

\section{Yöntem}

Ankara'da, şehrin merkezi sayılan Kızılay'a yürüyerek yaklaşık olarak 15 dakika mesafede bulunan Kurtuluş semtine gidildiğinde, kiralık ev ilanlarının bolluğu, semtin sokak aralarına yayılmış olan ikinci el eşya 
dükkânları ve öğrenci nüfusu dikkat çekecektir. Eğer bu semtte ev arayan biriyseniz, emlakçıda geçirdiğiniz kısa sürede dahi içeri girip çıkan öğrencilerin varlığını kolaylıkla fark edersiniz. Çevredeki üniversitelerden ötürü pek çok öğrenci Ankara'da ilkin buraya yerleşir ve muhtemelen çevrelerindeki komşu öğrencilerden aldıkları ikinci el eşyacı tavsiyeleriyle eşyalarını tamamlamaya çalışırlar. Bu semtte şuna rastlamak oldukça kolaydır: Kurtuluş'ta dükkânı olan kişi, halen gecekonduların bulunduğu İncesu'daki bir gecekonduyu eşya deposu olarak kullanmaktadır.

$\mathrm{Bu}$ girizgâh, çalışmanın sahası için neden Kurtuluş semtinin seçildiğinin bir nebze de olsa izahıdır. Çalışmanın ilerleyen aşamalarında detaylıca değinileceği gibi, bu bölgelerin çevresinde onlarca senedir pek çok üniversite bulunması, bu tercihin öncelikli sebeplerden biridir. Çalışma için bazı pilot görüşmelerle beraber semtte dükkânı bulunan Murat (41), Cemil (35), Tarık (52), Mustafa (44) ve Latif (51) isimli beş spotçu ile görüşme yapılmıştır. Görüşmecilerden yalnızca Cemil açıöğretim ile üniversiteyi bitirmiştir; Murat dışında liseyi bitiren görüşmeci olmamıştır. Toplamda spotçu dükkânlarında geçirilen zaman tahmin edildiğinden daha uzun sürmüştür. Her bir görüşmenin ortalama süresi üç saattir. Görüşme esnasında içeriye çok sık müşteri giriyor olması görüşmelerin sıklıkla bölünmesine ve uzamasına sebep olmuştur. Ayrıca görüşmecilerin zaman zaman konuyu farklı yerlere çekmesi (örneğin beyaz eşya almanın riskli olduğundan bahsetmeleri, yakın zamanda bir müşteriden gelen eşyalardaki sorunlar, o an içeri giren müşteriyle ilgili yorumlar vd.) görüşmelerin planlandığından daha uzun sürmesine neden olmuştur. Ancak bu aynı zamanda spotçular ile içeri giren müşteriler arasındaki iletişim biçimlerinin görülmesini, gözleme dayalı bilginin zenginleştirilmesini de sağlamıştır.

Saha sürecinde yapılan görüşmelerden çıkan bulgular, teorik çerçeveyle aynı anda yazılarak işlenecektir. Yani kavramsal çerçeve inşa edilirken, sahadan verilen örnekler, mefhumları anlamaya çalışmak için kullanılacaktır. Bu tercih metin içinde dağınıklık yaratma riskine sahip olsa da, metin yer yer monografik nitelik taşımasından ve buradaki spotçuların kendilerini bölgenin insanı olarak tanımlamasından kaynaklı olarak, aynı zamanda bir semtin tarihinin belirli bir dönemine şahitlik etmeleri açısından gereklidir. 
Saha için yapılan görüşmelerde spotçularla iletişime geçmek zor olmasa da, spotçulardan yalnızca bir kişi ses kaydı alınmasına pek sıcak bakmadı. Görüşülen spotçular isimlerinin olduğu gibi kullanılmasına izin verseler de isimlerinin değiştirilerek kullanılması tercih edildi.

Görüşmeler için yarı yapılandırılmış sorular hazırlanarak, görüşmenin gidişatına göre zaman zaman görüşmecilerin yeni konu açması sağlanarak serbest bir görüşme şekli tercih edildi. Spotçuların görüşmeye gönüllü olması sayesinde, çalışma kapsamında merak edilen bütün sorulara yanıt alındı. Görüşmecilerin hepsine sorulan kaç senedir bu işi yaptıkları, eğitim durumlarının ne olduğu ve bu işten memnun olup olmadıkları gibi genel soruların dişında şu sorular soruldu:

- Ö̈̆rencilerin yoğun olduğu bir bölgede çalışmanın farklılıkları olup olmadığ soruldu. Bu soru ile, spotçuların öğrencilerle çalışmakla diğgr müşteri grupları ile çalışmaları arasında bir fark görüp görmedikleri öğrenilmeye amaçlandi.

- Spotçular için okumanin ne anlama geldiği soruldu. Bu soru ile görüşmecilerin hem kendi eğitim durumları hem de zihinlerindeki eğitimli kişi algısının ne şekilde olduğu öğrenilmeye çalışıldt.

- Hangi öğrencilerin kendilerinden alışveriş yaptığı sorularak, iletişime geçtikleri öğrencilerin ekonomik durumlar hakkında ne kadar bilgi sahibi oldukları öğrenilmeye çalışıldı.

- Ö̈̆rencilerle iletişime geçmenin kendi hayatlarında bir değişiklik yaratıp

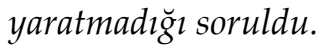

- Öğrencilerin yaşayıs biçimleri hakkında ne kadar bilgi sahibi oldukları soruldu.

- Öğrencilerin giyim kuşamları, konuşma biçimleri, kadın ve erkek öğrencilerin birlikte yaşaması, kadın öğrencilerin tek başlarına okumaya gelmeleri gibi sorular görüşmelerin akışına göre soruldu.

Çalışma kapsamında öncelikle az da olsa Ankara'nın yakın kentleşme tarihine bakmak faydalı olacağa benziyor. Zira görüşülen spotçuların, kendilerinin ya da babalarının başka şehirlerden Ankara'ya göçmüş olması bu tercihin meramı için gereklidir. 


\section{Kurtuluş Semti: Üniversiteler, Öğrenciler ve Esnaflar}

Ankara, Anadolu'nun bağrında bulunmasına ve Hitit dönemine dayanan zengin tarihine rağmen kentsel bir merkez olarak kısa bir geçmişe sahiptir (Özyeğin, 2004, s.18). Yirmi bin nüfusluk bir taşra kasabasıyken, 1923 senesinde Türkiye Cumhuriyeti'nin başkenti seçilmesinin ardından Ankara'nın kaderi tamamen değişmiştir. Planlı konutlar yapılmış, geniş caddelerle şehir donatılmış, opera binaları, kültür merkezleri ve kamu hizmet binaları ile Türkiye'nin modernleşmesinin simgesi olacak bir şehir yaratılmaya çalışılmıştır (s.18). Erken Cumhuriyet döneminde yeni toplumsal programları meşru kılmak amacıyla pek çok yeni kamusal alan yaratılmıştır; örneğin sinemada, parkta restoranda eğlenmek gibi yeni eğlence pratiklerin kazandırılması için yeni mağazalar, yeni kültürel mekânlar yaratılmıştır (Özaloğlu, 2009, s.25-26).

Türkiye'nin en planlı kenti olarak bilinen Ankara, diğer büyük kentlere göre daha hızlı büyümüştür. 1950 ile 1970 yılları arasında Türkiye'nin kırsal alanlardan gelen göçmen nüfusuyla ülkedeki en yüksek oranda kentsel nüfusun çoğaldığ 1 şehir olmuştur. 1997' de neredeyse 4 milyon insanı barındırır hale gelmiştir (Özyeğin, 2004, s.18). Günümüzde ise Türkiye İstatistik Kurumu'na göre Ankara'nın kayıtlı nüfusu 5 milyonun üzerindedir.

Bu kısa tarihsel süreçte Ankara'da kentli orta sınıfın yayılmasıyla birlikte inşa edilen yeni konutların yanı sıra kentte gecekondulaşma da artmıştır. Kurtuluş semtinde, yeni yapılan konutlarla gecekondular iç içe geçmiştir. Çevresinde bulunan kamu kuruluşları, devlet tarafından yaptırılan toplu konutlarının yanı sıra halen gecekondu bölgeleri bulunmaktadır. Günümüzde devam etmekle birlikte yakın zamanda pek çok gecekondu yıkılarak çok katlı apartmana dönüştürülmüştür.

“Kurtuluş, Cumhuriyet sonrası dönem Ankara'sının en karakteristik semtlerindendir. Kurtuluş'un, Ankara kent kimliğinin oluşumuna temel katkısı, şüphesiz, barındırdığı köklü eğitim kurumları ve kamu yapılarından ileri gelir (İmga, 2014, s.177)." Bu sebeple, semtin içerisinde geçmişten beri öğrenci yurtları bulunmaktadır. Semtin geçmişinde Konak Sineması, Site Sineması gibi mahallelinin yoğun olarak katıldığ 1 ve hatta tiyatro oyunlarının sergilendiği sosyal mekânlar bulunmaktaydı (2014, s.174175). Spotçulardan bazılarının da işaret ettiği gibi, Kurtuluş semtinde 
Rüştü Asyalı, Hakem Metin Tokat, Yeşilçam sanatçısı Baha ya da yazar Rasim Özdenören gibi ünlü simalar bir zamanlar Kurtuluş̧'ta yaşamış ya da halen yaşamaktalar.

Kısacası Kurtuluş, 1950'li, 1960'lı, 1970'li yıllarda 2-3 katlı müstakil bahçeli evlerin olduğu, aynı sokakta oturan herkesin ismen de olsa birbirini tanıdığı bir semtten, 1980'li yılların başından itibaren, yoğun bir yapılaşmayla değişime uğradı. Sonraki yıllarda semt sakinlerinin bir kısmı yeni oluşan semtlerdeki güvenlikli sitelere taşındı ve yerlerini civardaki okullarda öğrenim gören öğrencilere ve yakın hastanelerde çalışan sağlık personellerine bıraktı. Semtin görünüşü bu süreçle birlikte değişmiş oldu (2014, s.177). Gottdiener ve Hutchison'ın (2011, s.164) ifade ettiği gibi, varlıklı insanların kent içi ayrışması gönüllülük esasına dayanırken, yoksul kesimin bir arada kalması zorunluluktan kaynaklanmaktadır. Kurtuluş ve civarındaki semtlerde, öğrenciler çoğunlukla ekonomik sebeplerden ötürü yaşamayı tercih ederler. Öğrencilerin bir arada olması aralarındaki dayanışmayı da güçlendirmektedir.

\section{Kurtuluş Semti Çevresindeki Üniversiteler ve Öğrenciler}

Kurtuluş'a yürüme mesafesinde pek çok fakülte ve bölüm bulunduğundan bahsettik, bunlara değinmek gerekirse: Ankara Üniversitesi'nin Hukuk Fakültesi 1925 yılında, Dil ve Tarih-Coğrafya Fakültesi 1935 yılında, Siyasal Bilgiler Fakültesi 1936 yılında, Tıp Fakültesi 1940’lı yılların başlarında, Dişçilik Fakültesi 1960 yılında kurulmuştur. Hacettepe Üniversitesi'nin Tıp Fakültesi 1960'lı yıllarda, Dişçilik Fakültesi 1961 yılında kurulmuştur. Bu fakültelerin bulundukları kampüslerin içinde, pek çok farklı fakülte ve bölüm de yer almaktadır. Ayrıca bölgede 2009'da kurulan bir vakıf üniversitesi olan TED Üniversitesi de bulunmaktadır. Bölgede bu kadar çok üniversite bulunması sebebiyle, onlarca senedir binlerce öğrencinin yaşamayı tercih ettiği semtlerin başında Kurtuluş yer almaktadır. Bunların dışında, Kurtuluş'un Ankara'nın merkezi olan Kızılay'a yakın olmasına rağmen nispeten uygun emlak fiyatları yüzünden senelerdir öğrenciler bu bölgeleri tercih etmektedir. Örneğin Ayrancı, Tunalı gibi semtler de Kızılay'a ve bahsi geçen üniversitelere çok uzak olmamasına rağmen kiraların yüksek olması sebebiyle bu semtleri tercih eden öğrencilerin farklı ekonomik sinıflardan geldiğini söylemek 
mümkündür. Zaten bu semtler arasında fiyat karşılaştırılması yapıldığında aradaki fark ortaya çıkmaktadır. Örneğin Kurtuluş'ta genel olarak kira fiyatları, Tunalı'ya göre daha düşüktür.

Öğrencilerin Kurtuluş'taki yoğun nüfusu, semtin gündelik yaşantısında da görülebilecek izlere dönüşmüştür. Örneğin okul dönemi geçişlerinde, okullarını bitirip evlerine dönecek olan ya da ev değiştirecek olan öğrenciler semtte hareketlilik yaratırlar. Üniversite sonuçlarının açılandığı zamanlarda emlakçılara -zaman zaman aileleriyle birlikte- gelen pek çok öğrenci de bu hareketliliği arttırmaktadır. Buna bağlı olarak da yaz döneminde kiralık evlere olan rağbet artmaktadır. Bu semte has bir özellik olmamakla birlikte, evlerden eşyalarını çıkartan öğrencilerin bazıları, eşyaları çöp kutularının kenarlarına bırakmayı adet edinmişlerdir. Yalnızca öğrenciler değil, semtte oturan nüfus da çoğu zaman artık kullanılmayacak eşyalarını çöpün içine atmaz, kenarına bırakır.

Semt gezildiğinde sıklıkla emlakçıların ve ikinci el eşya satan dükkânların olduğu göze çarpmaktadır. Örneğin sadece Dede Efendi Sokak'ta toplamda altı tane emlak ve dört tane ikinci el eşya dükkânı bulunmaktadır. Semtlerde sokak aralarında, cadde üzerlerinde pek çok emlakçı ve spotçu bulunmaktadır. Mezun olan öğrencilerin kendi şehirlerine dönmesi ya da şehirden şehre hareket eden memurların dönemlik hareketleri nedeniyle bu bölgede emlak ofislerine siklikla rastlamak mümkündür. Sıklıkla karşı karşıya açılmış emlak ofisleri bulunmaktadır. İkinci el eşya satan dükkânların varlığı da -satılan ürünlerin kalitesini -eskiliğini düşününce- bölgede sınıfsal olarak değişen insanların ekonomik durumu hakkında fikir vermektedir. Çoğunlukla pek çok kez kullanılmış çalışma masası, gardırop, sandalye, yatak, buzdolabı vd. bir evin temel ihtiyac1 olan pek çok eski ürün satılmaktadır. Bu bölgede satılan ikinci el eşyalar çoğunlukla fiyat olarak düşük sayılabilecek seviyede, pek çok kişi tarafından kullanılmış ve tekrar satışa sunulmuş eşyalardır.

Spotçuların dükkânları genel olarak kapının önüne kadar taşan eşyalarla doludur. Spotçular, görüşmelerin yapıldığı 2018'in mayıs ayında "henüz öğrenciler çıkmadığı için" yeterince eşya olmadığını söyledi. Buna rağmen dükkânların içerisinde pek çok malzeme bulunmaktaydı. 


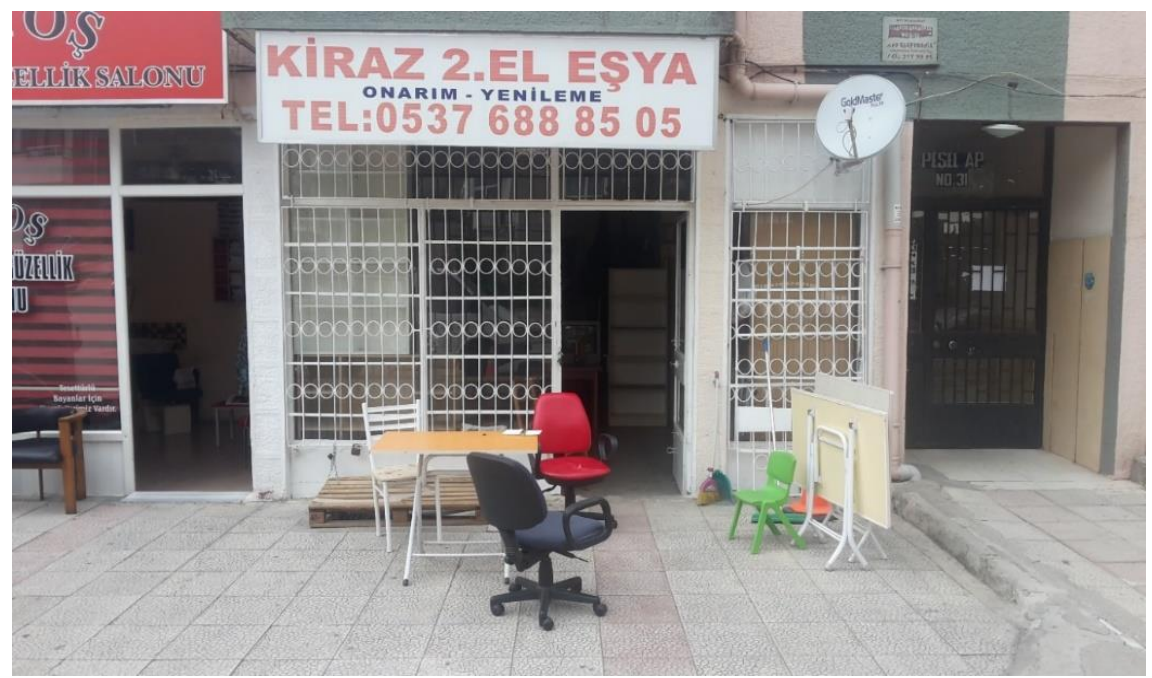

Fotoğraf 1: Dede Efendi Sokak üzerindeki spotçulardan birinin dışarıdan görünüşü.

Dükkânlar çoğunlukla sokak aralarında bulunsa da, Mahmut Esat Bozkurt Caddesi gibi, cadde üzerinde olan dükkânlar da mevcuttur. Bu iki konumlanma arasında ise eşyaların kalitesine ve fiyatlarına yansıyan -daha sonra detaylıca değinilecek- farklılıklar söz konusudur. Ancak dükkânların yapısı genellikle aynıdır. Dükkân içine dağılmış eşyalar, yan yana dizilmiş yataklar, bazalar, beyaz eşyalar, üst üste binmiş çalışma masaları; o masaların aralarına sıkıştırılmış tost makinesi, masa lambası, tüplü televizyon, yazıcı, bilgisayar klavyesi ve hatta su damacanasıpompası gibi bir evin ihtiyacı olabilecek hemen her şey yer almaktadır.

Dükkânın içindeki eşya akışı sebebiyle içeride, oturulacak sabit bir alan söz konusu değildir. Spotçular, dükkâna gelen koltuklardan ya da sandalyelerden o an oturmaya uygun olanının üzerinde oturup dinlenir ya da görüşmelerimizin çoğunda olduğu gibi, orada olan bir katlanır masayı açıp, etrafına sandalye atıp otururlar. Bazı spotçular, ellerine geçen bazı eşyaları kendileri de değerlendirebilirler. Örneğin Cemil, depo olarak aldığı bir yerde hoşuna giden eşyaları tutmaktadır. Ya da Tarık ve Mustafa, beğendiği bazı ürünleri köylerine götürmektedir. Murat, evindeki eşyaların hemen hepsinin ikinci el olduğunu söylemektedir. Latif ise diğer spotçulardan farklı olarak, ikinci el eşya kullanmamaktan yana olduğunu ifade etmektedir. 


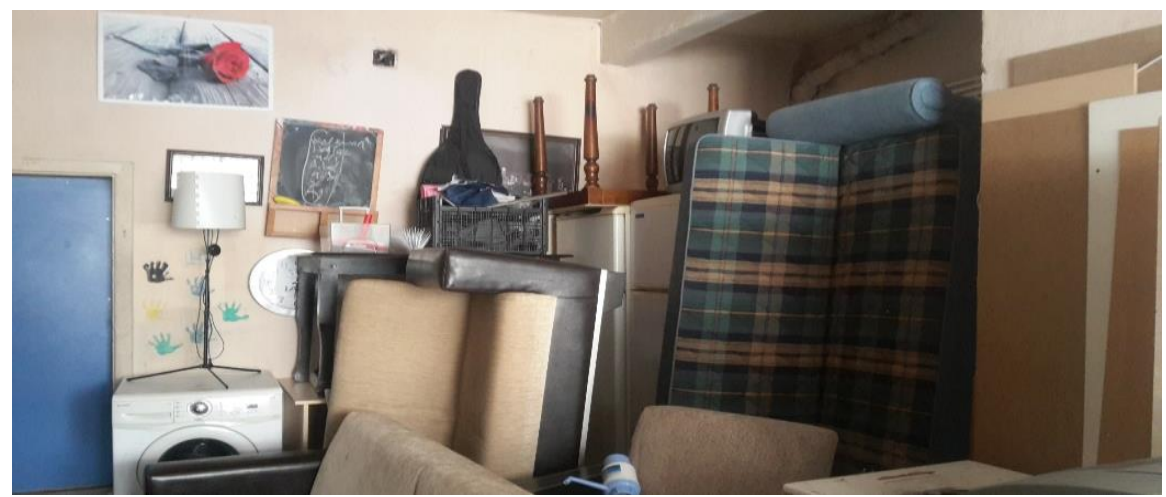

Fotoğraf 2: Çoğunun dükkânda -dönemine bağlı olarak- birkaç günden fazla kalmadığı eşyalar.

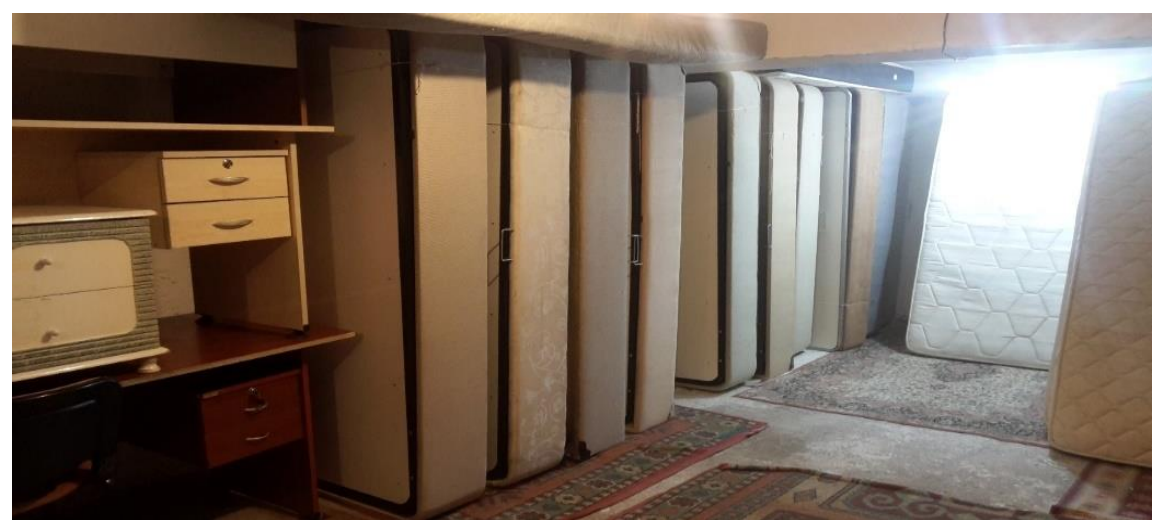

Fotoğraf 3: Baza, yatak ve masa yı̆̆ııları.

\section{Spotçu ve Öğrenci Karşılaşması: “Müşterilik Bitti Artık, Arkadaşız Biz”}

Öğrencilerin ve spotçuların neden Kurtuluş̧ta karşılaştığ1 düşünüldüğünde akla gelen olgulardan birisi göç olgusudur. Zira spotçular da, bölgedeki öğrencilerin çoğu da Ankara'ya farklı şehirlerden farklı amaçlar için geçici ya da kalıcı olarak geliyorlar. Görüşülen 5 spotçudan yalnızca birisi (Latif) Ankara, Kazanlı. Buna rağmen hepsi karşılaştıkları öğrencileri anlatırken "öğrenciler buraya okumaya geliyor" ifadesini kullandı. Bu durumun, Kurtuluş'taki karşılaşmanın bir iç göç sonucuna işaret ettiğini söyleyebiliriz. Öğrenciler her ne kadar müşteri olsalar da, spotçular için öğrencilerin her biri farklı bir kimliğe, farklı bir kültüre ve hikâyeye işaret 
ediyor. Spotçuların çoğu Ankara'ya yakın bölgelerden göçmüş olmalarına rağmen öğrencilerin çeşitli şehirlerden gelmiş olmaları farklı kültürlerin karşılaşmasına vesile oluyor. "İstanbul'dan havalı öğrenci de geliyor buraya, Diyarbakır'dan konuşmasını bilmeyen cahili de geliyor" diyen Latif, kendisini iki ayrı bölgeden gelen öğrenci için ayrı yerde konumlandırıyor. Ancak örneğin Mustafa, en başta İzmir, İstanbul gibi bölgelerden gelen öğrencilerle konuşmakta biraz çekindiğini; Anadolu'dan gelen öğrencilere kendini daha yakın hissettiği için daha rahat konuştuğunu ifade ediyor. Tarık ise öğrencilerle konuşa konuşa kullandığı Türkçenin bile düzeldiğini belirtiyor.

Stuart Hall'e (2014, s.284) göre, kimlik kavramsallaştırılmasının çetrefilli bir iş olmasının yanı sıra, kimlikler bir bakıma öznenin almak zorunda olduğu konumlardır. Bu konumlar da her daim bir yoksunluğa sahiptirler ve aslında ötekinin bulunduğu yerden inşa edilirler. Spotçu ve öğrencinin ilk bakışta karşılaşmasında ticaret yapan iki insandan başka sıra dışı hiçbir şey yoktur ve mal alıp mal satıldıktan sonra bütün hukuk sona ermiş gibi görünür. Ancak bu karşılaşma aslında çok daha fazlasına sebep olur. Sınıfsal olarak öğrenciden farklı bir yerde olsa da, spotçu öğrencinin evindeki dünyası karşısında zaman zaman büyülenebilir. Ancak aynı zamanda Cemil'in ifade ettiği gibi "biz onların evlerini, yaşam alanlarını düzenliyoruz sonuçta" diyerek de yaptığı işin yarattığı müştereklikten bahsetmektedir.

Müşterilerinin evlerine girerek, onların mahrem alanlarını gören ve hatta Cemil, Murat ve Latif'e göre onların mahrem alanlarını inşa eden spotçular, buna karşılık öğrencilerin dünyasıyla dönüşebiliyorlar. Görüşmeciler, üniversiteli olmanın ne demek olduğunu yalnızca onlarla kurdukları ilişki üzerinden kuruyorlar. Bu da onlar için tamamen farklı bir dünya demektir. Spotçular, ekonomik kökenli sermayeye sahip olsalar da, öğrencilerin kültürel sermayeleri olduğunu söyleyebiliriz. Bu sermayeler de zaman zaman çatışmalara ya da uzlaşmalara sebep olabilmektedir. Pierre Bourdieu'nün düşündüğü gibi düşünürsek; sınıflar arası çatışmaların salt ideolojik ya da salt ekonomik olarak belirlenemeyeceğini söyleyebiliriz. Sınıfsal ilişkileri ve çatışmaları belirleyen şeyler bundan çok daha fazlasıdır (Özsöz, 2007, s.17). Sınıfsal çatışmalarda zaman zaman farklı sermayelerin gücü devreye girer. Bu noktada Bourdieu farklı sermaye tiplerini tanımlar, bunlardan biri ekonomi temelli sermaye; 
diğeri de kültür temelli kültürel sermayedir. Kültürel sermaye, eğitim yoluyla edinilmiş davranış kalıplarını, estetik yargıları, kısacası bir anlam dünyasını ifade eder. Sermaye tiplerine örnek olarak görüşmecilerden Tarık'ın ifadesi gösterilebilir:

“İki-üçöğrenci geldi, Tarık Amca, Çayyolu'ndan bir abla bize eşya verecekmiş, onları almaya gider miyiz, dedi. Neyse konuştuk kadınla biz, gittik eşyaları almaya. Dandik bi' masayla ıvır zıvır eşyalar. Çocukları tee ayağına kadar yoruyor yazık. Bana ses etti kadın. Pist pist, gel bakiyim gel, al şu masayı çek şuraya, dedi. Öyle gicık oldum ki, ameleyiz ya ona göre. Bayan dedim doğru konuş, benim dört tane evim, dükkânım, köyde arazim var. Çocuklara çer çöp vermeye ayă̆ına kadar çă̆ırmışsın bi' de dedim, çocuklara gelin eşyanızı ben vericem dedim, döndük bizim dükkâna tekrar. İşte böyle tiplerle de karşılaşıyoruz bazen."

Tarık'ın bu anlatısında ekonomik ve kültürel sermayenin bazı anahtar kodları görülmektedir. Tarık'ın -belki- ekonomik durumu Çayyolu'nda öğrenciler için eşya alacağı kişi ile aynıken, edindiği mesleğin sınıfsal olarak alt tabakada görünen -onun ifadesiyle- amelelik olması kültürel sermayede onu gene aşağı bir konuma çekmektedir.

Görüşmelerin çoğunda bu iki kavram arasında paslaşma fark ediliyor:

Birincisi ekonomiyle bağlantıll, sınıfsal olan karşılaşma. Spotçuların ekonomik durumlarının öğrencilere göre kat be kat daha iyi olduğunu söylemek mümkün. Aylık ortalama kârlarının 3000 - 4000 TL civarında olduğunu söyleyen spotçuların, çoğunun bir ya da ikiden fazla mülkü var.

İkincisi ise ekonomik farklılığı aşan, öğrencilerin kültürel sermayelerinin yarattığı karşılaşma. Öğrencilerin çoğunluğu ekonomik olarak spotçulardan oldukça daha alt seviyede olmasına rağmen kullandıkları dil dahi spotçular tarafından farklı olarak görülmektedir.

$\mathrm{Bu}$ sebeple iki ayrı alt başlık altında, önce ekonomik temelli karşılaşmanın yaşandığı ve spotçuların "sonuçta ticaret" diyerek işlerine baktıkları ekonomik sermayelerin hâkim olduğu alana bakılacaktır. Ardından da öğrenciler ve spotçular arasında, spotçuların "öğrenciler benim siyasi görüşümü bile etkiledi" diyerek işlerinin onları dönüşüme götürdüğü kültürel sermayelere bakılacaktır. 


\section{Sosyal Sermayeler: "Sonuçta Müşteri Ama..."}

Öğrencilerin bölgede ikinci el eşya satıcılarıyla sıklıkla iletişim içinde olmasının ilk sebebi ekonomi temellidir. Spotçulara "öğrenciler neden sizden eşya alıyor" sorusu sorulduğunda, çoğunun yanıtı ekonomik temelli olmuştur. Çoğu satıcı "parası yok, öğrenci işte ne yapsın ki, beş kuruş geçiyor cebine" benzeri yanıtlar vermiştir. Öğrencilerin ekonomik durumları düşünüldüğünde, eğer aileden para alınmıyorsa, ya gündelik işlerden kazandıkları parayla ya da Kredi Yurtlar Kurumu'nun aylık verdiği kredi ${ }^{2}$ ile geçinmektedirler. Ek gelir olmadan, tek başına bu miktarlar yoksulluk sınırının çok altındadır. Bu yüzden öğrencilerin ikinci el eşya almaya yönelmesi olağandır. Görüşme yapılan spotçulara "abi öğrenciyiz" ifadesinin onlara ne çağrıştırdığı sorulduğunda, çoğu "pazarlığın geleceğini biliyoruz" diyerek tebessüm etmiştir.

Bütün görüşmecilere göre, Kurtuluş'ta bulunan öğrenci potansiyeli bu bölgede ikinci el eşya işinin başlamasına sebep olmuştur. Spotçuların öğrencilerle ilişkilerini sıkı tutması sosyal sermayeleri ile ilgilidir. Sınıf mefhumu, sosyal evrende özerkliği oluşmuş bir kültürel ve sosyal alanın derin belirleyiciliği ve eğitim mekanizmalarıyla ilişkilendirilerek anlaşılabilecek hem sosyal hem de kültürel bir kategoridir (Arll, 2014, s. 149). Öğrencilerin bölgedeki varlığı sebebiyle yeni iş sahaları oluşmasının yanı sıra farklı ilişki tiplerini de yaratmıştır. Bir spotçunun bir öğrenciyle iyi ilişki kurması, iyi bir alışveriş süreci yaşaması gerekmektedir; zira bunun sonucunda öğrencilerin arkadaşlarına tavsiyesi ile spotçu yeni müşteri kazanacaktır. Spotçuların sosyal sermayeleri sayesinde öğrencilerden iş aldığ1 söylenebilir. Öğrenci spotçuya yeni bir müşteri getirdiği gibi, spotçu da öğrenciye evindeki bir başka sorunu çözmesi için (örneğin tesisat, elektrik, boya badana vd.) kendi çevresinden bir başkasına yönlendirerek yardımcı olabilmektedir.

“Ben 15 sene falan önce nakliyecilik yapıyordum arabam vardl, üç dört tane nakliyede çalıştı̆̆ım firma vardr. Daha sonra hem nakliyecilik yaptım hem de mobilya mağazasında kurulum ustasıydım. O dönemde de sifır götürüp eski getiriyordum ya, elime eşya geliyor. (...) öğrenciler fikir verdi bana. Ya amca siz işte nakliyeye gidiyorsunuz, hiç buzdolabı çıkıyor mu, elinizde eşya var mı falan. İşte

\footnotetext{
22019 itibariyle lisans için 500, yüksek lisans için 1000, doktora için 1500 TL'dir.
} 
aklıma bir fikir geldi, sonradan da Ulus'tan eşyaları alayım, ben bu semtte yapayım bu işi dedim. (...) Latif'inkiyle benimki burada ilk işte." (Tarık)

Latif ve Mustafa zamanında Ulus'ta bir dükkâna sahipken, hem oradaki müşteri ve esnaf ilişkisinin yıpratıcılığı hem de Kurtuluş'ta da bu işin yapılacak olması onları mekân değişikliğine itmiş.

“Benim yer İtfaiye'deydi. Burada iş olmaz normalde diye düşündüm ama baktık burada da oluyor, hem de bezdik yani İtfaiye'den, oradaki müşteri biraz zor yani (Latif)."

Öğrencilerin spotçularla yakın ilişki kurması, satıcıların aynı öğrencinin evine birden fazla girip çıkması, aralarında oluşan iletişimi arttırmaktadır. Örneğin Cemil, bazı evlere girip öğrencilere acıdığını ve evdeki tamir tadilat işlerini herhangi bir ücret almadan yaptığını belirtmiştir. Mustafa, neredeyse bütün müşterilerinin öğrenci olmasına rağmen zaman zaman onlara acıyıp hiç para almadan evlerindeki bütün arızalar gidermeye çalıştığını ifade etmiştir. Ancak cadde üzerinde yeri bulunan Latif ise bu konuda diğerlerine göre daha mesafeli. Latif'in sattığ 1 eşyalar diğerlerine göre daha temiz ve daha az kullanılmış durumda. Bu durumda denebilir ki, dükkânlar sokak aralarına kaydıkça öğrencilerin tercih etme oranı daha da artıyor. Latif'in de dediği gibi, "benim müşterimin yarısı ailedir ya da bekâr memur, asker filandır, benim eşyalarım temiz çünkü hem de cadde üstünde memur kesimi oturur. Öğrenci de gelir ama benim eşyalarım biraz daha pahalı öğrenci için." Ancak bu ifadenin devamında Latif şunları ekleyerek öğrencilerle diğer müşteriler arasında bir farkı ortaya koymaktadır: "Ama ben öğrenciyi severim müşteri olarak, çünkü öğrenci emeğe saygı duyar."

Latif'in bu ifadelerinden sonra sorulan, "peki sence öğrencinin eline geçen para nereye gidiyor" sorusuna yanıtı, "eşya alırken en eskisini alır ama işte Kizılay'da kafelere gidip oturur, kahve içer filan, parasını orada harcar" yanıtı ise öğrencinin eline geçen -spotçuya göre- paranın hangi sermayede değerlendirildiğine işaret ediyor. 


\section{Farklı Sermayeler, Farklı İlişkilenmeler: “Benim Çok Öğrencim Oldu”}

Şehir her türden ve her sınıftan insanın, gönülsüzce ya da agnostik bir biçimde de olsa bir araya gelerek durmadan değişen, gelip geçici ama yine de müşterek bir yaşantıyı ürettiği bir mekândır (Harvey, 2015, s. 117). Kentin bu özelliği bazı mesleklere, gelip geçici iletişimin ötesinde bir amaç yüklemiştir. Taksi şoförü, kuaför / berber ya da mahalle bakkalı kentin zorunlu biçimde de olsa bir araya getirdiği insanlar arasında sosyal bir katık özelliği taşır. Örneğin mahalle kuaförü müşterisinin ismini bilir, sokağın nabzını ölçer ve mahallenin muhtarı gibi (Şenel, 2017, s. 112) mahalleyle ilgili bilgi sahibidir. Kurtuluş'ta görüşülen spotçular da benzer tavrı sürdürmektedir, hatta Tarık bir dönem gerçekten muhtar olmayı dahi düşündüğünü ifade etmiştir: “Öğrenciler beni destekleyecektir, evlerinin içine kadar girdik zaten."

Görüşmelerde dikkat çeken, spotçuların ilkin vurguladıkları estetik yargılarındaki değişimdir. Bourdieu, Ayrım kitabında habitus kavramı aracılığıyla izah etmeye çalıştı̆̆ 1 toplumsal ve kültürel olarak beğeninin biçimlenme şeklini, estetik yargıların sınıfsal yatkınlıklarla bağlantılı olduğunu ifade eder. Kitapta kısaca Bourdieu, toplumsal hiyerarşide bireyin konumunda yükselme oldukça beğeni yargisında soyutlaştırma başlayacak demektedir (2015b, s. 73). Spotçular için ise durum öğrencilerin evlerine girip çıkmakla, onlarla sohbet etmekle başlamıştır. Bu işi İtfaiye'de yaptığında, ne kadar ağır ve kocaman eşya varsa değerli olduğunu düşündüğünü söyleyen Tarık, öğrenci evlerine girip çıtıktan sonra bütün fikri zamanla değişmiştir:

"Buraya gelip palet sordular, kasa sordular. Yok dedim, onlarn zaten bulunca yakıyoruz kışın, burda kırıp. Garip de geldi tabi. Ben onu soran öğrencilerin evine gittim bir gün. Yatak yapmışlar, köşe yapmışlar eve. Döşek gibi, şark köşesi gibi. O kadar hoşuma gitti ki dedim ben bundan aynisından köyde yapıcam. Yaptım ayn köşeyi, sonra başka evde gördüm bi de boyamışlar öğrenciler bunları. Ya dedim nerden geliyor aklınıza. Vernikledim boyadım ben de... Öğrenciler benim her şeyimi değişstirdi işte, köydeki eşyalarımın bile rengi değişti." (Tarık)

\footnotetext{
${ }^{3}$ Mustafa'nın tanıdığı öğrencilerden biri için ifadesi. Buna benzer ifadeyi bütün görüşmeciler kullanmakta.
} 
“Öğrenciler gelip sandalye ayağı bile soruyorlar. Sandalye ayağını kim n'apsin ama burda oluyor işte, allyorlar. Gidiyorsun bi bakıyorsun bir şey yapmışlar onlarla. Benim çok hoşuma gidiyor. Ben İtfaiye'deki gibi kocaman eşek ölüsü şeyler almıyorum artık. Ufak işte kullanışl güzel şeyler bulup alıyorum, onları satıyorum. Ben de beğenmiyorum zaten öyle." (Murat)

Öğrencilerin kültürel sermayelerinin kendi sermayelerinden farklı olduğunu gören spotçular, eski iş yerlerinin bulunduğu Sanayi, İtfaiye Meydanı gibi yerlerden sonra öğrencilerle çalışmayı tercih etmişler. Hepsi zamanında görünürde daha homojen grupların bulunduğu yerlerde çalıştıkları için, hepsine öğrencilerle çalışmanın, daha önceden çalıştıkları mekânlara göre ne gibi farkı olduğu sorulduğunda şunu ifade ettiler:

"Biz buraya alıştı. Oraya Irakh geliyor, Suriyeli geliyor... Ama bizim semtimiz hep öğrenci, öğrenciyle çalışmak istiyorum ben. Gidip Mamak'ta daha büyük ve daha ucuz bir dükkân tutabilirim ama buradaki gibi düzgün müşteri potansiyelini bulamam. Diyalogum zayıf olur, ben orada yapamam. Eskiden yapardım ama şimdi değişti. Buraya alı̧̧ım, hep böyle genç, okumuş, düzgün insanlarla konuştuğunda hiç başın ağrımıyor. Ama, daha kaba olacak ama cahil adamlarla diyalog ettin mi olmuyor. Mesela geçen gün bulaşık makinesi sattık, götürdük, çalıştıramadık. Ben ufak bir şeyi var biliyorum ama, acaba neden neden... Çocuk dedi abi, Ingilizcesi var, bunun timer'ını dedi bak devreye sokmuşuz. Bir saat sonra iki saat sonra devreye sokmuşuz. Çözdü mesela. Ben bunu bilmeyen birine götürsem, ben n'apcam mesela, adam bozuk der kavga eder benimle. O yüzden, hani, uzlaşmact yani öğrenci. Bunlar hoş şeyler, insanı insan hissettiriyor, üzmüyor yani. (...) Burada olmak İtfaiye'de olmaktan iyi, adam çok kazanır orada ama çok başı ağrır. Biz burada az kazanıyoruz ama kafamız rahat. Ben bak kaç yıldır aktif yapıyorum, bir kere bile bir öğrenciyle tartışmadım. Bu çok önemli." (Cemil)

$\mathrm{Bu}$ diyalogdan biraz sonra içeriye giren bir müşteri konuşmamızı bölüyor. Pihlip marka çamaşır makinesi olduğunu, Cemil'e onu kaç paraya alabileceğini soruyor. Cemil müşteriye Philips'in çamaşır makinesi üretmediğini, elindekinin başka bir şey olabileceğini söylüyor. Müşteriyle de pek ilgilenmeden dükkândan geri yolluyor. Ardından bana dönerek şunu söylüyor: "İşte bak markanın adını bile söyleyemiyor daha, okumuşuyla mı çalışırsın böyle sallamasyon iş yapacaklar mı?"

Spotçuların öğrenci ya da memurlarla çalışma isteğinin daha fazla olduğunu söylemek mümkün. Hatta Latif haricinde sokak aralarında 
dükkânı olan spotçuların müşterilerinin büyük çoğunluğu öğrenci ve öğrencilerle çalışmaktan oldukça memnunlar. Diğer müşteri kesimini küçümseyici yaklaşımları bütün spotçularda çokça gözlemlendi. Spotçuların öğrencilerle iletişim kurmayı tercih etmesi ekonomik olmasının yanı sıra sinıfsal bir hareketliliğe de tekabül ediyor.

“Öğrenci emeğini görüyor insanın, öteki gibi kaba saba değil. Hani öylesi de var ama genel olarak öğrenciler iyidir. İtfaiye'deyken ben böyle değildi, hep bizde tetikteydik gelen giden müssteri yüzünden. Saygısız kaba." (Latif)

"Ben seviyorum öğrencileri ya, gelip konuşurlar, selam verirler, arkadaşlık yaparı, çay kahve bir şey içeriz, konuşuruz. Buradan başka yere gitmem yani şimdi." (Mehmet)

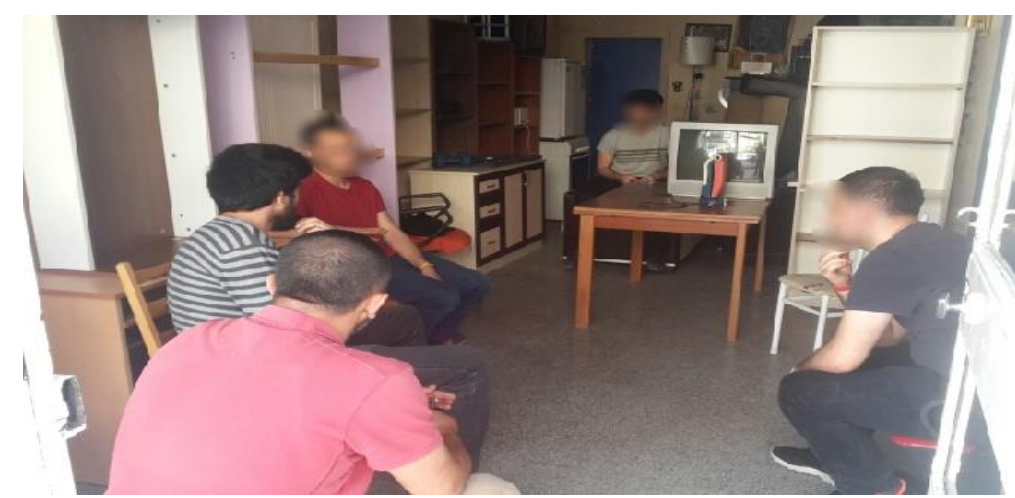

Fotoğraf 4: Görü̈sme esnasında içeri giren öğrenciler ev ararken yaşadıkları sıkıntıları spotçu (mor tişörtlü) ile ve o esnada orada bulunan diğer öğrencilerle paylaşırken.

Spotçularla öğrenciler ticari ilişkinin yanı sıra pek çok konuda sohbet için de bir araya geliyorlar. Tarık, bir öğrenciden Olympos'u duymuş bir sohbet esnasında. Tatillerde sürekli köyüne gidip gelen Tarık, bir gün de böyle yerleri denemek istediğini söyledi. Murat, bir keresinde dükkânına gelen ve kendisini hippi diye ifade eden bir öğrenciden duyduğu şeyi daha önce duymadığı için pişman olduğunu ifade etti: "Eğer, valla bak hippilik diye bir şey olduğunu bileydim, daha eskiden duymuş olsaydım valla hiç uğraşmazdım böyle işlerle." Kimi zaman bu sohbetler ev sahipleriyle ilgili yaşadıkları sorunla ilgili olurken, kimi zaman güncel siyasi konularla ilgili olabilmektedir. Tarık bu tip sohbetler sayesinde yeni şeyler öğrendiğini, konuşmasının dahi değiştiğini söylüyor: 
"Ben bu işi yapmadan önce insanlarla konuşmayı dahi beceremezdim, yani zaten muhatap olduğumuz adamlar da öyleydi öküz gibi. Şimdi özgüven geldi artık, kendimi anlatıyorum, çünkü gelen çocuklar sana selam veriyor, iki eşya alıp verdikten sonra seninle konuşuyor, hal hatır soruyor. Bizim bilmediğimiz açılardan görmemizi să̆hlyorlar. İyi yani öğrenciler."

Bir görüşme sırasında iki öğrenci içeri girdi. Bir aydır ev aradıklarını; şu an bulundukları sokakta yokuş çıkmaktan yorulduklarını (Altay Sokak), mahallenin yokuşunun neredeyse olmadığı Samur Sokak civarına taşınmak istediklerini, ancak ev sahiplerinin bekâr oldukları için evlerini vermediklerinden dert yand. "Veterinerlik okuyoruz, doktoraya başlıyorum seneye, kadın diyor ki bekâra asla vermem evimi" benzeri bir ifade kullanan öğrenciler, o esnada içeride bulunan ve ev arayan iki öğrenci ve spotçu ile dertlerini paylaştılar. Ev arayan diğer öğrenciler, eğer bu iki öğrenci vakitlice evden çıkarlarsa onların evlerine geçeceklerini konuştular. Spotçunun mekânı, öğrencilerin dertleşme mekânına dönüşebilmektedir. Üstelik bu konulardan meselenin ülkedeki ekonomik duruma doğru kayması öğrencilerle spotçular arasındaki ilişkiyi zaman zaman farklı bakış açılarından bireylerin yan yana geldiği kamusal bir alana dahi dönüştürmektedir.

"Benim hayata bakış açım değişti burada. Ben, yani çok, böyle, at gözlü̆̆̈̈ varmış bende. Hiçbir yeri görmüyormuşum. Sadece kendi bildiğimi doğru zannediyormuşum, burada benim önyargılarım, her şeyim kırıldı. Particilik, ülke yönetimi... Mesela beğendiğ̈im bir model olur eşyada filan, o bile değişti mesela. Çünkü ufkumu çok açtı. (...) Eskiden olsa hemen vurup atardım ama bura beni yumuşattı. Siyasi olarak da yani... (Cemil)

Bourdieu, habitus kavramının makro ya da mikro, bütüncül ya da bireycil pek çok ikilikleri aşmada önemli olduğunun altını çizer. Nesnel yapıların varlığını reddetmeyen Bourdieu, bu yapılar konusunda da bir mücadele alanı olduğunu söyler. Yani ona göre habitus, alanın güçleri ile mücadeleye girerken aynı zamanda kendi yatkınlıklarını değiştirmeye ya da alanın gücünü kendi yatkınlıklarına göre değiştirmeye çabalar (2013a, s. 74). Spotçular da, sosyal sermayelerini kaybetmemek ve ekonomilerini sürdürebilmek için öğrencilerle iyi iletişim kurmak zorunda hissederler kendilerini. Bu zorunluluk, zaman zaman onları dönüştürür, zaman zaman ise çatışmalara yol açar. Spotçular sahip oldukları habitusların 
yaratıcılıklarıyla bazı engelleri aşmaya çalışırlar. Bu çatışmaları görebilmek için spotçularla görüşüldüğünde "kızlı-erkekli yaşamak hakkında neler düşünüyorsun, erkek bir öğrencinin uzun saçlı ve küpeli olmasıyla ilgili neler düşünüyorsun, kadın öğrenci sence tek başına yaşayabilir mi, öğrencilerin ailelerin uzakta yaşamaları hakkında neler düşünüyorsun, senin çocuğunun başka bir şehirde okumasını ister misin" benzeri sorular soruldu.

Bu noktalarda spotçular bazı ifade değişikliklerine gittiler. Spotçuların hepsinde okuyana karşı bir öykünme durumu olduğunu söylemek mümkün. Bu öykünme, (imkân olsaydı) okumak isteyip istemedikleriyle ilgili konuşurken ifade ettiklerinden anlaşılmakta. Ancak bu öykünme zaman zaman tersine dönebiliyor: "Okuyor ama bi' selam vermesini bile bilmiyor, havalı oluyor bazıları." Okuyan için yükledikleri bazı ahlaki anlamlar var. Örneğin bunlardan biri bir arada yaşama konusu. Bütün öğrenciler çok iyi, emeğin ne olduğunu biliyor derken; kızlı-erkekli yaşamak konusunda hepsi çok katı davrandılar.

“Benim İtfaiye'de dükkânım varken öğrenciler de gelirdi oraya, tek kişilik yatak baza alıp çıkarlardı. Buraya geldim, ben var ya, tek kişilik yatak satamadım. En çok çift kişilik yatak sattım öğrencilere. Yahu olmaz, evli değilse, şey değilse kızla erkek birlikte yaşayamaz bence. Ama alıştık tabi artık, ne yapalım, iyisini vermeye çalışıyoruz şimdi. Bizim (Kayaş'tan) mesela akrabalar geliyor bazen, işte öğrenciler yatak alıp gidiyor. Böyle bakıyorlar, garipsiyorlar işte, yahu bu ne Latif der gibi bakıyorlar. Biz alıştık artık." (Latif)

Buna benzer ifadeleri tek bir spotçu hariç hemen hepsi söyledi. Hemen bütün görüşmeciler için (Murat hariç) kadın ve erkeğin birlikte yaşaması yanlış. Fakat onlar için "kız öğrencilere yazık." "Ben üzülüyorum kızlara, yazık oluyor." Erkek öğrencilerin bir kadın öğrenciyle yaşaması "haytalıktan başka bir şey değilken (Latif)" kadın öğrencinin yapmaması gereken bir hareketten öteye geçmiyor. "Erkeklere bir şey olmuyor, kızlar kendileri üzülüyor sonra, ayrılıyorlar, atıyor eşyaları, bedavaya veriyor resmen bize (Cemil)."

\section{Sonuç}

İkinci el eşya dükkânları, yalnızca bir ticaretin gerçekleştiği değil, farklı karşılaşmaların yaşandığı, bir noktadan sonra dertlerin paylaşıldığı ve öğrenciler arası dayanışmanın dahi sağlanabildiği bir alana dönüşüyor. 
Spotçularla beraber güncel siyasi meseleler tartışıldığı gibi öğrencilerin problemleri de konuşulabiliyor, spotçunun nakliye aracı için ödediği verginin miktarı da... Spotçuların "benden aldıkları eşyalarla okudular, öğrencilik bitti halen arkadaşızdır" dedikleri müşterileriyle konuştukları kimi meseleler onların zihinlerinde dönüşüme yol açmış olsa da, "gene de ben çocuğumu şehir dışında okutmam" benzeri ifadelerle de aslında temelde karşılaşmanın sonucundan kaçınma ve çatışma da söz konusu. Ancak gene de kimi spotçular, politik görüşlerine kadar farklılığa gidebiliyor; iktidarların baskın ideolojilerine karşın en azından müzakere edebiliyorlar ya da Cemil gibi "sağ görüşlü biri olarak solcuları tanıorlar." Yahut tersi biçimde, örneğin Murat gibi "sol görüşlü biri olarak sağ görüşten öğrencilerle" iletişime geçebiliyorlar. Bu durum elbette farklılıkla karşılaşmanın tersine, var olan görüşlerinin pekişmesine de sebep olmaktadır.

Kadın öğrencilere karşı tutum, spotçuların onlara "üzüntü duymaları" ile gerçekleşse de "kız öğrenci de okusun tabi" benzeri ifade bütün spotçular arasında yaygın. Latif alıştığı ancak bir türlü kabul edemediği kadın ve erkek öğrencinin bir arada yaşamasına karşın şuna cevap arıyor: "Okusun ama yurt mu yok onlara?" Diğer spotçular için de durum aynı.

Bu çalışma, öğrencilerle sıklıkla ilişki içinde olan ikinci el eşya satıcılarının bu süreçte karşılaştıkları farklılıklara karşı deneyimleri anlaşılmaya çalışılmıştır. Gündelik yaşamda, sıradan diyaloglar ve karşılaşmalardan dahi anlam fışkırabilir (Lefebvre, 2015b, s. 115). Kurtuluş'taki öğrenci ve spotçu karşılaşmalarında da bu durum sahada değinildiği biçimde görülebilmektedir. Ancak spotçuların anlattıklarından anlaşıldığı kadarıyla, oldukça farklı ideolojiden, farklı alanlardanbölümlerden ve farklı bölgelerden-kültürlerden öğrencilerle karşılaşmaktadır. Bu karşılaşmalar spotçuların önyargılarının zamanla kırılmasına sebep olsa da, farklılıklarla karşılaşmak her zaman köklü bir değişikliğe neden olmuş gibi de görünmemektedir. 


\section{EXTENDED ABSTRACT}

\section{Reading Class Confrontations with The Help Of Cultural Reproduction: Second-Hand Store Owners In Ankara, Kurtuluş}

Furkan Dilben

Hacettepe University

The accelerating urbanization process, in the 1950s, caused many people to immigrate from rural areas to urban areas in Turkey. The reason for this migration is inadequate job opportunities in rural areas while urban areas have too much of it, and this movement of migration is continuing. Today, so many people migrate to cities - temporarily or permanently - due to reasons such as education or jobs. By this migration, several people communicate with a variety of reasons. Within the scope of this study secondhand store owners, in Kurtuluş district of Ankara, where there are many universities within walking distance, have been examined.

The second-hand store owners have intense communication with the university students in this district. The relationship between the students and the owners is featuring the field study of the paper. The dealers, who have set up a second-hand store when they realize a potential population movement in Kurtuluş after moving to Ankara years ago and working in various jobs, are constantly in communication with the students who are biggest customer group of them. This intense relationship between students and second-hand store owners has never been studied in academic literature.

For the study, the researcher had interviews with five second-hand store owners named Murat (41), Cemil (35), Tarık (52), Mustafa (44) and Latif (51) who have stores in the district. The time spent in the stores during the field study has been longer than expected. 
A loose interview style which provides participants to bring up new topics when it is needed has been preferred. For the interview, semi-structured questions have prepared. Thanks to volunteered second-hand store owners, all the questions that have been wondered are answered.

The reason why Kurtuluş district is chosen is that there are many universities such as Ankara University, Hacettepe University, and TED University around the district. Therefore, so many students have preferred to live in Kurtuluş for many years. When the district is walked about, one can notice that there are many real estate agencies and second-hand stores. For example, just in Dede Efendi Street, there are six real estate agencies and four second-hand stores in total. In the district, there are many real estate agencies and second-hand stores in the alleys and on the avenue. It is possible to frequently come across to real estate agencies due to graduating students who are returning their hometown or move to another city, or government officials move from city to another. There are many real estate agencies positioned very close to each other. It gives an idea about the economic condition of the people living in this neighbourhood when the poor quality and the oldness of the products sold in the second-hand stores is considered. Many old second-hand housewares which may be needed for a house such as desks, wardrobes, chairs, beds, refrigerators, etc. are sold in these stores. Most of the housewares sold in this district are considerably cheap; used by many people and put on the market to resell.

The store owners who carry the housewares bought by students to their home and see their private sphere, and who are - as mentioned by Cemil, Murat, and Latif- building their private sphere up in one sense, are having a chance to chat with students. These little talks are transforming the owners. The interviewees are learning the meaning of being a student just with the help of the communication they have with the students. This means a totally different world for them. Even though the second-hand store owners have economic capital, it can be said that the ones who have the cultural capital are students. These capitals may cause conflicts or reconciliations from time to time. When we think just like Pierre Bourdieu, it can be said that interclass conflicts cannot be purely ideological or purely economic.

Different dimensions of intercultural encounter occur during the communication between second-hand store owners and students. Sometimes, 
a store owner becomes peasant when s/he encounters with a student coming from Istanbul, while they urbanize in the presence of a student coming from a rural area like Diyarbakir. They sometimes feel oppressed vis-à-vis the education level of a student, even though they have economic superiority. The second-hand store owners who gush over the education from time to time, sometimes at the events like a student do not say hi to them, they talk in an insulting manner about students. Apparently, being educated requires behaving virtuously for the store owners, and this points to a difference.

The second-hand stores transform into not only an area that people merchandise, but also an area that people experience various encounters, that they share their sympathy after a while, and an area that provides inter-students solidarity. One can have a conversation with students and store owners about recent political topics, the problems of students, and the taxes the owners paid for their transportation vehicle. Even though some topics the store owners talk with their customers, whom about they say "students finished their educations with the housewares they bought from me; their education is over but we are still friends", transformed their thoughts, it is obvious that they experience conflicts and avoidance of the results of the encounter when they say things like "still, I don't let my kid educate out of town". On the other hand, some second-hand store owners can at least discuss the dominant ideologies of government or like Cemil " they get to know left-wingers as a rightist," while some of them can change their political opinion. Or, on the contrary, just like Murat they can communicate with "rightist students as a left-winger."

This study focuses on the experiences of the second-hand store owners who have different cultural capital than students. This study shows us that class encounters, which seem ordinary in daily life and cannot be reduced totally to the economy might be studied through cultural encounters.

\section{Kaynakça / References}

Arlı, A. (2014). Klasik sosyolojide derin revizyon: Pierre Bourdieu sosyolojisi., (G. Çeğin, Der.) Ocak ve Zanaat Pierre Bourdieu Derlemesi içinde (s. 131-160). İstanbul: İletişim Yayınları. 
Bourdieu, P. (2013a). Bilimin toplumsal kullanımları: Bilimsel alanm klinik bir sosyoloji için. (L. Ünsaldı, Çev.) Ankara: Heretik.

Bourideu, P. (2015b). Ayrım: Beğeni yargısının toplumsal eleştirisi. (D. Fırat, Çev.) Ankara: Heretik.

Gottdiener, M., ve Hutchinson, R. (2011). The new urben sociology. Boulder: Westview Press.

Hall, S. (2014). Kimliğe ihtiyaç duyan kim? (F. Mollaer, edt.) , Kimlik Politikaları: Tanınma, Ödeşlik ve Farklılık, içinde (s. 277-300). Ankara: Doğu-Batı Yayıncılık.

Harvey, D. (2015). Asi şehirler: Şehir hakkından kentsel devrime doğru. (A. D. Temiz, Çev.) İstanbul: Metis.

İmga, H. (2014). Ön Cebeci mahallesi, Nâm-1 diğer Kurtuluş semti, Idealkent Kent Araştırmaları Dergisi, 11, 172-177.

Lefebvre, H. (2012a). Gündelik hayatın eleştirisi I. İstanbul: Sel Yayınları.

Lefebvre, H. (2015b). Gündelik hayatm eleştirisi II: Gündelik Hayat Sosyolojisinin Temelleri. (I. Ergüden, Çev.) İstanbul: Sel Yayıncılık.

Özaloğlu, S. (2009). Sakinlerinin Anılarında Ankara'nın Mekânsal Yaşanmışlığı: 1935-1950. Dosya Dergisi, 25-35. http://www.mimarlarodasiankara.org/dosya/dosya16.pdf Erişim Tarihi: 24.06.2019

Özsöz, C. (2007). Giriş, Pierre Bourdieu'nün temel kavramlarına. Sosyoloji Notlarn, 15-21.

Özyeğin, G. (2004). Başkalarının kiri: Kapıcılar, Gündelikçiler ve kadınlık halleri. İstanbul: İletişim Yayıncilık.

Şenel, B. (2017). İçeriden dışarıya, dünden bugüne: Mahalleye açılan kapı olarak kuaför salonu., (F. Ş. Cantek, Der.) Aynanın Önünde Cımbızın Ucunda içinde (s. 111-146). İstanbul: İletişim

\section{Kaynakça Bilgisi / Citation Information}

Dilben, F. (2019). Sınıfsal karşılaşmaları kültürel sermayeler üzerinden okumak: ankara, kurtuluş ikinci el eşya satıcıları. OPUS-Uluslararası Toplum Araştırmaları Dergisi, 11(18), 569-593. DOI: 10.26466/opus.572111 